Study Report 2001-03

\title{
Effectiveness of Distance Learning for the Battle Staff NCO Course
}

Debra J. Drenth, U. Christean Kubisiak, and Walter C. Borman

Personnel Decisions Research Institutes

\section{Advanced Training Methods Research Unit \\ Franklin L. Moses, Chief}

\section{U.S. Army Research Institute for the Behavioral and Social Sciences} 5001 Eisenhower Avenue, Alexandria, Virginia 22333-5600

$$
\text { June } 2001
$$

